THURSDAY, JULY 6, 1876

\section{A PHYSICAL SCIENCE INSTITUTE}

PROBABLY the present generation knows little of the conditions under which the great exhibition of $185 \mathrm{r}$ was organised, or of the important results which followed it. After clearing all the expenses of that enterprise, a large surplus remained, to administer which a Royal Charter was granted to the Commissioners who managed the Exhibition. Since 1852 the Commissioners have held numerous meetings, and quietly done a large amount of work from which the nation has reaped great benefit. Much of the success of the various departments connected with the South Kensington Museum is due to the help they have been able to give, and now they propose a scheme whereby a large proportion of the property at their disposal will be allotted for the benefit of science and art. The Commissioners recently held a meeting, under the presidency of the Prince of Wales, at which their Special Committee reported on various schemes for making use of their funds and property.

The Commissioners started with a clear capital of 186,000\%. They have given to the Government, for the use of the South Kensington Museum, property valued at $14,000 l$, and $60,000 \%$. in land. They have sold to the Governmient, at half the value, land for the Natural History Museum, worth $240,000 \%$. They have given the site of the Royal Albert Hall, worth 60,000 ., and retain property in it to the extent of $80,000 l$. They have invested roo,oool. in the galleries lent to the India Museum and Science Loan Exhibition. Notwithstanding these very considerable contributions, the Commissioners still possess out of the Kensington Gore estate, which they purchased with the surplus funds of the I85 I enterprise, landed property of very great value. We believe that the whole of the site of the International Exhibition buildings, including, the Horticultural Gardens, and some adjacent properties are in the trust of the Commissioners. Five schemes have been thought of for the utilisation of this valuable property. By one of these the Commissioners could realise one million sterling, and yet retain a square of ten or twelve acres in the centre of their property. But this they do not think of adopting. The one which they seem to regard most favourably is to lease or sell the ground outside the arcades, called the East and West Annexes, and retain the Horticultural Gardens and Exhibition Buildings, by which means they would realise upwards of $350,000 l$., free from all liabilities. Whichever scheme is adopted-and the Commissioners seem to think the time is ripe for making the best of their trust in "the interests of science and art "-a very large sum will be at their disposal,

Various objects, all in accordance with the purpose for which they were originally appointed, seem to have suggested themselves to the Commissioners for the appropriation of these funds. Scholarships in science and art, it is suggested, might be founded in connection with central institutions and provincial colleges of science and art, such as those at Manchester, Birmingham, Bristol, Leeds, and elsewhere. It would be a great benefit, it is thought, to these new institutions if their more promising students could be brought up to the Vor. xIV.-No, 349 laboratories of chemistry, physics, and biology, which are in active work at South Kensington. A portion of the funds might also, it is thought, be devoted to the promotion of museums of science and art throughout the country, and in making grants in aid of the British Section at International Exhibitions; also in supplying several existing wants in connection with the South Kensington Museum, and erecting other buildings on the estate to be devoted to science and art.

The Commissioners are naturally anxious for the welfare of their own child, the South Kensington Museum, and for the proper exhibition of the treasures it contains, and the proper housing of its educational and other libraries. This has engaged much of their attention, more especially as the executors of the late Mr. Dyce insist on the carrying out of the provisions of his will with regard to the display of his bequest. Since the subject, however, has been under the consideration of the Commissioners, Government has made a grant of $80,000 \mathrm{l}$. for the purposes of Art, part of which will, no doubt, be devoted to the proper location of the Dyce and other collections, and to some of the other purposes concerning which the Commissioners are naturally anxious. Had they been aware of this grant, no doubt they would have spoken more fully and decidedly of another scheme which appears to have come under their consideration.

The scheme to which we refer was briefly described by Mr. Cross recently in the House of Commons, and has reference to the establishment of " a museum and scientific institute, which would comprise a library of works in science and art, for the use of students at South Kensington, and public examination rooms." From the way in which the library is here mentioned we may consider that it is a matter of secondary importance in the eyes of the Commissioners, and that the main idea is to build a museum and laboratory. We confess we cannot see the immediate appropriateness of attaching a library to a laboratory and museum of this kind. At present no library of science exists, and there will be a library attached to the Natural History Museum which is now being erected on the Commissioners' grounds, and there are various places in London where the best works and serials in all departments of science can be easily consulted. There is at least no pressing need at present for a science library, while the necessity for the organisation of a laboratory and museum was never more urgent. It is known that if only a suitable receptacle were provided, many of those who have contributed to the Loan Collection are willing to leave their apparatus permanently as the nucleus of an English Conservatoire des Arts et Métiers. No better opportunity could be afforded for the commencement of a science museum; but if the Commissioners do not resolve without delay to carry out the scheme that has apparently been engaging their attention, a golden opportunity will be lost that is not likely to occur again soon.

As to the proposal to provide rooms in the Science Museum for examinations in connection with the Science and Art Department, we think the Commissioners would be doing a quite unnecessary and rather mischievous thing in carrying out such a proposal. Government has started these examinations, and is no doubt quite prepared to provide examination-rooms for itself. I 
needs no leading in this matter, though it certainly does need encouragement to take under its wing a science museum and laboratory. This then it seems to us ought to be the first care of the Commissioners, leaving the examination rooms out of the reckoning, while the library can easily afford to wait for future consideration. If the idea of a library is brought too prominently to the front, we fear the building will come to be known by this and no other name, and come in the end to be mainly, if not only, what its name purports. We believe the Commissioners could spare 100,cool. for a Science Museum; and we are sure the great success which has attended the Loan Collection will tend to confirm them in their intentions, and induce them without delay to set about providing a permanent successor. We have no doubt that the Commissioners are quite alive to the value of a Physical Science Museum and Laboratory, and feel strongly the great need there is in this country for such an institution. They have on the whole done their work conscientiously and well, and South Kensington testifies to the highly important and beneficial results which they have accomplished. By erecting an institution for the promotion of physical science, they will show their anxiety to make their work complete in all the departments with which they have had to deal. Twenty years ago they started the Museum of Art at Kensington; if twenty years hence a Museum of Science has made equal progress, the nation will have reason to congratulate itself on the result, and be grateful to the Commissioners for the faithfulness with which they have done their work.

\section{WHEWELL'S WRTTINGS AND CORRE- SPONDENCE}

William Whewell, D.D., Master of Trinity College, Cambridge. An Account of his Writings, with Selections from his Literary and Scientific Correspondence. By I. Todhunter, M.A., F.R.S., Honorary Fellow of St. John's College. (London : Macmillan and Co., 1876.)

TE frequently hear the complaint that as the boundaries of science are widened its cultivators become less of philosophers and more of specialists, each confining himself with increasing exclusiveness to the area with which he is familiar. This is probabiy an inevitable result of the development of science, which has made it impossible for any one man to acquire a thorough knowledge of the whole, while each of its sub-divisions is now large enough to afford occupation for the useful work of a lifetime. The ablest cultivators of science are agreed that the student, in order to make the most of his powers, should ascertain in what field of science these powers are most available, and that he should then confine his investigations to this field, making use of other parts of science only in so far as they bear upon his special subject.

Accordingly we find that Dr. Whewell, in his article in the "Encyclopadia Metropolitana," on "Archimedes and Greek Mathematics," says of Eratosthenes, who, like himself, was philologer, geometer, astronomer, poet, and antiquary : "It is seldom that one person attempts to master so many subjects without incurring the charge and perhaps the danger of being superficial."

It is probably on account of the number and diversity of the kinds of intellectual work in which Dr. Whewell attained eminence that his name is most wideiy known. Of his actual performances the "History" and the "Philosophy of the Inductive Sciences " are the most characteristic, and this because his practical acquaintance with a curtain part of his great subject enabled him the better to deal with those parts which he had studied only in books, and to describe their relations in a more intelligent manner than those authors who have devoted themselves entirely to the general aspect of human knowledge without being actual workers in any particular department of it.

But the chief characteristic of Dr. Whewell's intellectual life seems to have been the energy and perseverance with which he pursued the development of each of the great ideas which had in the course of his life presented itself to him. Of these ideas some might be greater than others, but all were large.

The special "pursuit, therefore, to which he devoted himself was the elaboration and the expression of the ideas appropriate to different branches of knowledge. The discovery of a new fact, the invention of a theory, the solution of a problem, the filling up of a gap in an existing science, were interesting to him not so much for their own sake as additions to the general stock of knowledge, as for their illustrative value as characteristic instances of the processes by which all human knowledge is developed.

To watch the first germ of an appropriate idea as it was developed either in his own mind or in the writings of the founders of the sciences, to frame appropriate and scientific words in which the idea might be expressed, and then to construct a treatise in which the idea should be largely developed and the appropriate words copiously exemplified-such seems to have been the natural channel of his intellectual activity in whatever direction it overflowed. When any of his great works had reached this stage he prepared himself for some other labour, and if new editions of his work were called for, the alterations which he introduced often rather tended to destroy than to complete the unity of the original plan.

Mr. Todhunter has given us an exhaustive account of Dr. Whewell's writings and scientific work, and in this we may easily trace the leading ideas which he successively inculcated as a writer. We can only share Mr. Todhunter's regret that it is only as a writer that he appears in this book, and it is to be hoped that the promised account of his complete life as a man may enable us to form a fuller conception of the individuality and unity of his character, which it is hard to gather from the multifarious collection of his books.

Dr. Whewell first appears before us as the author of a long series of text-books on Mechanics. His position as a tutor of his College, and the interest which he took in University education, may have induced him to spend more time in the composition of elementary treatises than would otherwise have been congenial to him, but in the prefaces to the different editions, as well as in the introductory chapters of each treatise, he shows that sense of the intellectual and educational value of the study of first principles which distinguishes all his writings. It is manifest from his other writings, that the composition of these text-books, involving as it did a thorough study of the fundamental science of Dynamics, was a most appro- 